\title{
A Long Dead Woman from Bethany is Saddened to See Lazarus Swept Away
}

Before he was pulled so suddenly away, it amazed her how fated their meeting seemedboth having lived within the same lifetime, albeit

at alternate ends: she dying just a year after his birth. It turned out his family had married into hers some four generations back, indeed many of his livestock were seeded from bulls and fowl her grandfather had driven fifteen furlongs in emigration from Jerusalem.

And amid the hazy din of the dark, heavily populated cave, they spoke of many things they had in common-

of the people they knew: sisters, brothers, nephews, children of the community now grown and working at tilling the family land-

of their mutual surprise at the overcrowded nature of heaven, or hell, or where ever this place was that looked so very much like a crypt in which an entire village might bury its parentsof the wants and needs of the spirit in a realm without pain, without pleasure,

without water, wind, fire, or even solid stone, without a single sensation reminiscent of life except the panicked impression

of gasping for breath as though in drowning.

And for four days they strolled through many caves, some barren and sandy 
like their own, others decorated with fine paints and dyes, still others packed with tokens and treasures accumulated in life,

but each sealed tight from the air and light with stones or cubit upon cubit of earthtombs packed and fuming with the wet, vague folk

of death: with their raucous talk, the footfalls of their wanderings, with the recollections of their lives or, in the case

of the wispy few so much longer here, deaths; a muted song echoing from the damp walls.

And to save him from dread at the lack of breath, she listened patiently, spoke softly, kept him silent company,

wondering all the while how he looked under the swaddling gravecloths that covered every feature but the black of his eyes-

knowing that soon enough he would forget his body, would tire enough of life to remove the bandages himself: shedding his last

earthly chattel to walk freely through the stone, out into the light, and dark, of a new set of days and a new set of nights. 